\title{
Utilization of Liposomes for Correction of the Metabolic and Bactericidal Deficiencies in Chronic Granulomatous Disease
}

\author{
GHAZALLY ISMAIL, LAURENCE A. BOXER, ${ }^{(31)}$ AND ROBERT L. BAEHNER \\ Department of Pediatrics, Division of Pediatric Hematology-Oncology, James Whitcomb Riley Hospital for Children \\ and the Indiana University School of Medicine, Indianapolis, Indiana, USA
}

\begin{abstract}
Summary
IgG-coated liposomes containing glucose oxidase (GO) in order to provide a means of generating $\mathrm{H}_{2} \mathrm{O}_{2}$ were prepared. Leukocytes from patients with chronic granulomatous disease (CGD) which are lacking a means of generating $\mathrm{H}_{2} \mathrm{O}_{2}$, ingested the IgG-coated liposomes and metabolic oxidative deficiencies of glucose-1- ${ }^{14} \mathrm{C}$ oxidation and iodination were normalized. Both of these activities have been shown to depend upon the availability of $\mathrm{H}_{2} \mathrm{O}_{2}$ within polymorphonuclear leukocytes. Improvement in the capacity to kill Staphylococcus aureus by chronic granulomatous disease leukocytes were observed under similar conditions. Thus, it is possible to restore the oxidative metabolic capacities to CGD leukocytes by the introduction of glucose oxidase containing liposomes to these cells.
\end{abstract}

\section{Speculation}

It is possible to restore the oxidative metabolic capacities and to obtain moderate improvement in the bactericidal functions in vitro of CGD leukocytes by providing the cells ingestible liposomes containing GO. Further studies might define more efficient methods for introducing oxidase activity into these cells, or employing drugs that generate $\mathrm{H}_{2} \mathrm{O}_{2}$.

CGD is a genetic disorder of leukocyte function characterized by lack of normal oxidative metabolic activities associated with phagocytosis. These oxidative activities include, in part, increased glucose-1 $-{ }^{14} \mathrm{C}$ metabolism (13), iodination of ingested particles $(21)$, and production of superoxide anion $\left(\mathrm{O}_{2}^{-}\right)(9)$, and hydrogen peroxide $\left(\mathrm{H}_{2} \mathrm{O}_{2}\right)(1,14)$ which are necessary for efficient killing of catalase positive microorganism $(18,20)$. In vitro improvement of the metabolic and bactericidal deficiencies of CGD leukocytes has been achieved utilizing glucose-oxidase coated latex particles $(5$, 17) and an $\mathrm{H}_{2} \mathrm{O}_{2}$-producing dapsone derivative, 4-hydroxylaminodiphenyl sulfone (16). The enhanced metabolic response of the CGD leukocyte could be ascribed to both extracellular and intracellular elaboration of $\mathrm{H}_{2} \mathrm{O}_{2}$. Recently, enzyme replacement therapy utilizing liposomes as carriers of entrapped enzyme has been employed as a means to specifically replace the deficient enzyme $(10,28)$. Liposome utilization eliminates the risk of directly introducing immunogenic foreign proteins into the circulation and delivers entrapped enzyme to selective target cells. Despite intensive attempts to identify the enzymatic basis for lack of enhanced enzyme activity during phagocytosis by CGD leukocytes, the failure of these cells to reduce oxygen indicates either a missing or defective oxidase $(2,4,7,12)$. However, it is generally agreed that the pathologic basis for recurrent infection lies with the failure of these PMNs ${ }^{\dagger} \mathrm{O}$ generate $\mathrm{H}_{2} \mathrm{O}_{2}$ and other oxidants $(4,9,14)$. In this study, substitution of an $\mathrm{H}_{2} \mathrm{O}_{2}$-generating enzyme, glucose oxidase in liposomes opsonized with IgG, allowed for selective intracel- lular restoration of both metabolic and bactericidal capacities of CGD leukocytes utilizing GO containing liposomes.

\section{MATERIALS AND METHODS}

\section{SOURCES AND PREPARATION OF PMN LEUKOCYTES}

Venous blood was collected from normal adult volunteers and three unrelated patients with CGD. The diagnosis was confirmed in each case by the failure of the leukocytes to reduce nitroblue tetrazolium dye (4) and to kill $S$. aureus 502A normally (24). The leukocytes were separated from the heparinized blood by sedimentation of the erythrocytes at $37^{\circ} \mathrm{C}$ with $6 \%$ dextran (Pharmacia Fine Chemicals, Ind., Piscataway, NJ). The leukocyte-rich fraction was centrifuged at $250 \mathrm{~g}$ for $10 \mathrm{~min}$ at $4^{\circ} \mathrm{C}$ and contaminating erythrocytes were removed by hypotonic lysis. The cells were washed and resuspended in Krebs Ringer Phosphate buffer (KRP), pH 7.4. Cell suspensions contained approximately $80 \%$ PMN and with greater than $90 \%$ viability by trypan blue exclusion test.

\section{PREPARATION OF AGGREGATED IgG-COATED LIPOSOME CONTAINING GLUCOSE OXIDASE (IgG-Lip-GO)}

IgG-Lip-GO were prepared as previously described by Weissman et al. (27). L- $\alpha$-Lecithin (L- $\alpha$-phosphatidyl choline) from egg yolk, dicetyl phosphate, and cholesterol were purchased from Sigma Chemical Co., St. Louis, Missouri. Briefly, lecithin, dicetyl phosphate, and cholesterol were dissolved in chloroform and added to a $100 \mathrm{ml}$ round bottom flask at a molar ratio of $7: 2: 1$ in a total volume of $6 \mathrm{ml}$. The lipids were dried using a rotary flashevaporator (Buchler Instrument, Fort Lee, NJ) in a $37^{\circ} \mathrm{C}$ water bath until a uniform thin lipid layer was formed on the walls. A $4 \mathrm{ml}$ aqueous solution of either active GO or heat-inactivated GO $\left(100^{\circ} \mathrm{C}\right.$ for $\left.30 \mathrm{~min}\right)$ at a concentration of $1.0 \mathrm{unit} / \mathrm{ml}$ was added and the flask was flooded with $\mathrm{N}_{2}$ gas. Two glass beads were added to the flask and the lipid film was dislodged off the wall by vortexing. The preparation was briefly sonicated at $4^{\circ} \mathrm{C}$ with a Bronson sonifier, Model W140, at a setting of 3 for four intermittent 15 -sec periods. The resulting cloudy suspension was allowed to swell at room temperature for $2 \mathrm{hr}$ and layered on a Sepharose $4 \mathrm{~B}$ column $(2.7 \times 36 \mathrm{~cm})$ equilibrated with $6.7 \mathrm{mM}$ phosphate buffer, $\mathrm{pH}$ 7.2. Liposomes were eluted and the effluents were collected in $5 \mathrm{ml}$ fractions. The fractions were analyzed for lipid content by determining absorbance at $520 \mathrm{~nm}$. Glucose oxidase activity was determined as described previously (8). Latent glucose oxidase activity in the liposomes was determined after incubation of the fractions with an equal volume of $1 \%$ Triton $X-100$ at $37^{\circ} \mathrm{C}$ for $30 \mathrm{~min}$. The liposome-rich fractions were pooled and centrifuged at $100,000 \mathrm{~g}$ for $1 \mathrm{hr}$. The pellet was suspended in $0.1 \mathrm{M}$ phosphate buffered saline and adjusted to an optical density of 0.4 at $530 \mathrm{~nm}$. 
Human IgG was obtained from Miles Laboratory, Inc., Elkhart, Indiana, and used without further purification. The lyophilized IgG was reconstituted with $0.01 \mathrm{M}$ phosphate buffer (pH 6.5) and the $\mathrm{pH}$ was adjusted to 7.3 with $1 \mathrm{M} \mathrm{Na} \mathrm{HPO}_{4}$. The IgG solution was heat-aggregated for $10 \mathrm{~min}$ at $62^{\circ} \mathrm{C}$, then incubated with liposomes for $25 \mathrm{~min}$ at $37^{\circ} \mathrm{C}(100 \mu \mathrm{g} \mathrm{Agg-IgG/ml})$.

\section{PHAGOCYTOSIS OF IgG-Lip-GO BY PMN LEUKOCYTES}

The phagocytic mixture contained $0.5 \mathrm{ml}$ of PMN suspensions $\left(1 \times 10^{7}\right.$ cells $\left./ \mathrm{ml}\right), 0.5 \mathrm{ml}$ of IgG-Lip-GO and $0.2 \mathrm{ml}$ of fresh normal serum. The tubes were incubated for $60 \mathrm{~min}$ in a $37^{\circ} \mathrm{C}$ shaking water bath. To determine the ability of PMN to ingest IgG-Lip-GO, phagocytosis was blocked either by the addition of cytochalasin B $(5 \mu \mathrm{g} / \mathrm{ml})$ or by placing the tubes in ice bath. After incubation, the tubes were centrifuged at $250 \mathrm{~g}$ for $10 \mathrm{~min}$ and the pellets were washed three times before resuspending in $0.5 \mathrm{ml}$ of phosphate buffered saline, pH 7.3. An equal volume of $1 \%$ Triton $\mathrm{X}-100$ was added and the solutions were sonicated for three 15sec periods at $4^{\circ} \mathrm{C}$ to ensure complete release of glucose oxidase from both the cells and the liposomes.

\section{MEASUREMENT OF $\mathrm{H}_{2} \mathrm{O}_{2}$ RELEASE FROM PMN LEUKOCYTES}

PMN were incubated with IgG-Lip-GO as described above. Sodium azide $(1 \mathrm{mM})$ was added to the leukocyte previously to inhibit catalase and prevent the breakdown of $\mathrm{H}_{2} \mathrm{O}_{2}$ released from the cells. After $30 \mathrm{~min}$ of incubation, the tubes were centrifuged at $30,000 \mathrm{rpm}$ for $25 \mathrm{~min}$ and the supernatants were placed on ice for later quantitation of $\mathrm{H}_{2} \mathrm{O}_{2}$ release. The rate of $\mathrm{H}_{2} \mathrm{O}_{2}$ release into the extracellular medium by CGD leukocytes during phagocytosis of IgG-Lip-GO was measured by a modification of the method described by Root et al.(26). Briefly, $0.4 \mathrm{ml}$ of $50 \mu \mathrm{M}$ scopoletin (Sigma Chemical Co.) was added to the supernatant and the tubes were incubated for an additional $30 \mathrm{~min}$. Next, 0.4 $\mathrm{ml}$ of horseradish peroxidase $(1 \mathrm{mg} / \mathrm{ml})$ was added and the decrease in fluorescence was monitored in a spectrophotofluorimeter using KRP as the blank. The amount of $\mathrm{H}_{2} \mathrm{O}_{2}$ released was calculated from a standard $\mathrm{H}_{2} \mathrm{O}_{2}$ curve using an extinction coefficient of $81 \mathrm{M}^{-1}$ at $230 \mathrm{~nm}$ (15).

\section{MEASUREMENT OF GLUCOSE-1- ${ }^{14} \mathrm{C}$ OXIDATION}

The hexose monophosphate shunt (HMP) activity was determined as previously described by Baehner et al. (1). The incubation mixture contained $0.5 \mathrm{ml}$ of PMN $\left(1 \times 10^{7}\right.$ cells $\left./ \mathrm{ml}\right), 1 \mu \mathrm{Ci}$ of glucose- $1-^{14} \mathrm{C}, 0.1 \mathrm{ml}$ fresh human serum and various concentrations of IgG-Lip-GO. As appropriate, the reaction mixture was adjusted to $1.0 \mathrm{ml}$ final volume with KRP. Normal PMN phagocytizing latex particles served as the positive control for the stimulation of HMP activity.

\section{MEASUREMENT OF IODINATION ACTIVITY}

The iodination of opsonized zymosan particles ingested by PMN leukocytes was determined as previously described by Hakim et al. (11). The reaction mixture contained $0.5 \mathrm{ml}$ PMN $\left(1 \times 10^{7}\right.$ cells $\left./ \mathrm{ml}\right), 4 \mathrm{~nm}\left(\mathrm{I}^{125}\right)-\mathrm{NaI}, 0.1 \mathrm{ml} \mathrm{zymosan}(\mathrm{ml} / \mathrm{ml})$, and various concentrations of IgG-Lip-GO. The reaction volume was adjusted to $1.0 \mathrm{ml}$ with KRP. Normal PMN phagocytizing opsonized zymosan served as the positive control for increased iodination activity.

\section{MEASUREMENT OF BACTERICIDAL ACTIVITY}

The bacterial killing assay was performed by a modification of the method described by Quie et al. (24). The reaction mixture contained $0.5 \mathrm{ml}$ of PMN leukocytes $\left(5 \times 10^{6}\right.$ cells $\left./ \mathrm{ml}\right), 0.1 \mathrm{ml}$ fresh human serum, and $0.4 \mathrm{ml} S$. aureus 502A (approximately 5 $\times 10^{6}$ bacteria $/ \mathrm{ml}$ ), and 0.1 or $0.2 \mathrm{ml}$ of IgG-Lip-GO.

\section{RESULTS}

\section{ENTRAPPING AND LATENCY OF GLUCOSE OXIDASE WITHIN LIPOSOMES}

A representative elution profile of the liposome preparation obtained from Sepharose 4B column is shown in Figure 1. The fractions rich in liposomes, as indicated by the lipid peak, possessed minimal glucose oxidase activity. However, after treatment of the liposome fractions with the lipolytic agent Triton X-100, glucose oxidase activity could be demonstrated, indicating latent

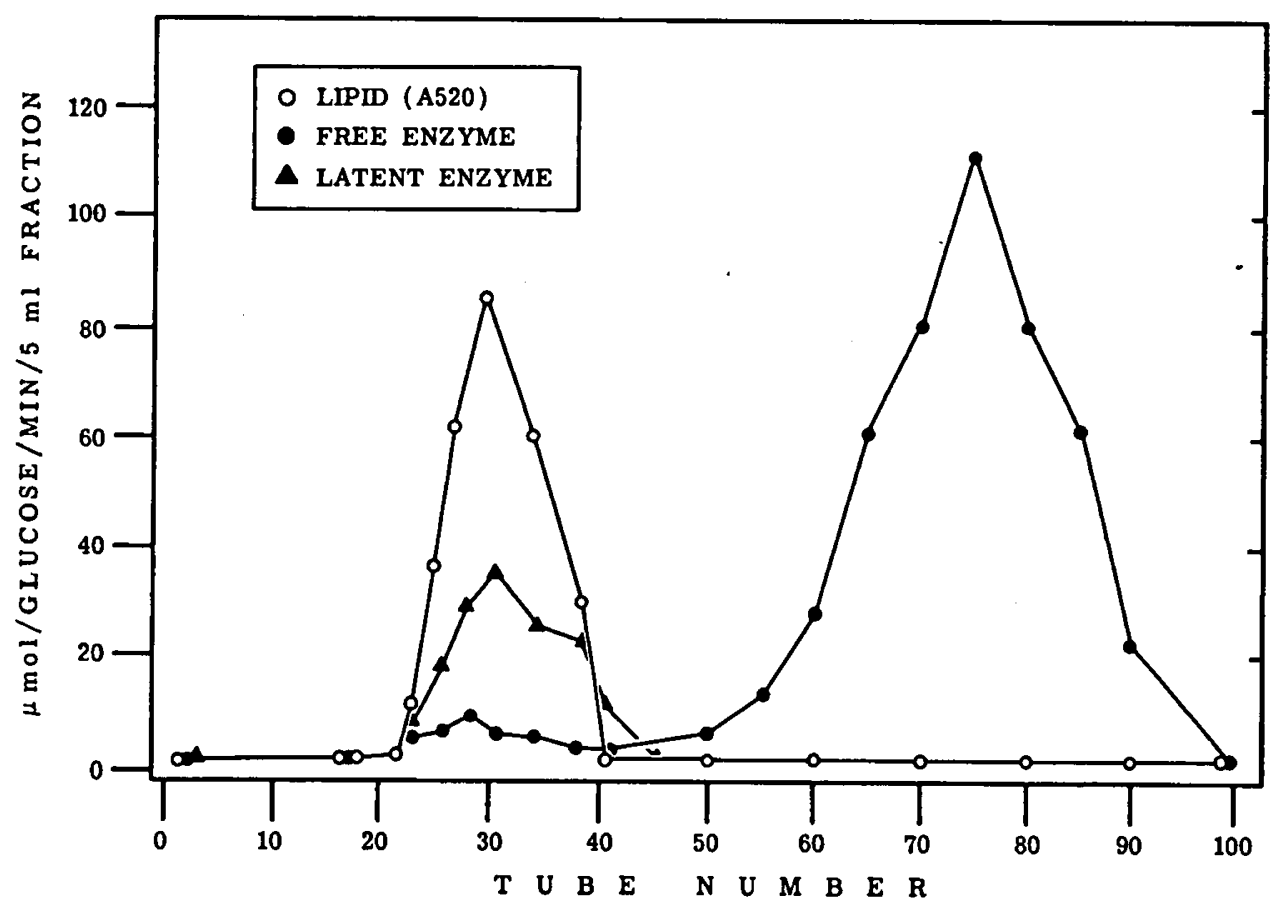

Fig. 1. Separation of liposomes containing entrapped glucose oxidase from free enzyme on a Sepharose $4 B(2.7 \times 36 \mathrm{~cm})$ column. Liposomes were prepared with lecithin, dicetyl phosphate, and cholesterol in a molar ratio of 7:2:1 and mixed with glucose oxidase solution (1.0 unit/ml). Latent enzyme was determined after treatment of the liposome fractions with Triton X-100 (See Methods). 
activity in the fractions, corresponding to the lipid peak. Glucose oxidase activity associated with the lipid fractions varied from one preparation to another, but as much as $5-11 \%$ of the total glucose oxidase activity was latent within these lipid fractions.

\section{PHAGOCYTOSIS OF IgG-Lip-GO}

After phagocytosis of IgG-Lip-GO, glucose oxidase activity was demonstrated in the cellular pellet (Table 1). The pellet contained 2 -fold greater enzyme activity $(P<0.025)$ than those pellets obtained from cells in which phagocytosis was inhibited by either cytochalasin B or ice bath temperatures. Correspondingly, glucose oxidase activity in the supernatant was inversely related to the amount of enzyme activity in the respective pellets. These observations suggest that the liposomes were internalized by the CGD leukocytes.

\section{$\mathrm{H}_{2} \mathrm{O}_{2}$ RELEASE}

To determine whether the IgG-Lip-GO released enzymatically active glucose oxidase after ingestion, the rate of $\mathrm{H}_{2} \mathrm{O}_{2}$ release into the extracellular medium during phagocytosis was quantitated. As noted in Table $2, \mathrm{H}_{2} \mathrm{O}_{2}$ production by $\mathrm{CGD}$ leukocytes was negligible during resting states and failed to increase significantly $(P<0.4)$ during ingestion of latex particles. The addition of IgGLip-GO increased the rate of $\mathrm{H}_{2} \mathrm{O}_{2}$ release by approximately 25fold. Treatment of the CGD PMN with cytochalasin B significantly $(P<0.001)$ attenuated the amount of $\mathrm{H}_{2} \mathrm{O}_{2}$ release after exposure of these cells to IgG-Lip-GO. In a separate experiment, cytochalasin B failed to lyse the IgG-Lip-GO (data not shown). It would, therefore, appear that cytochalasin B treatment only partially inhibits the uptake of the IgG-Lip-GO permitting some generation of $\mathrm{H}_{2} \mathrm{O}_{2}$ by the CGD leukocytes to occur.

\section{GLUCOSE-1 $-{ }^{14} \mathrm{C}$ OXIDATION}

In contrast to normal PMN, incubation of CGD leukocytes with latex particles did not stimulate HMP shunt activity (Table 3). In the presence of IgG-Lip-GO, HMP shunt activity was significantly increased $(P<0.025)$ in the PMN leukocytes of all CGD patients studied. The stimulation was proportional to the amount of liposomes present in the incubation mixture. An increase of glucose- $1-{ }^{14} \mathrm{C}$ oxidation up to 5 -fold was observed in samples treated with $0.3 \mathrm{ml}$ of IgG-Lip-GO and the enhanced activity was prevented by heat inactivation of glucose oxidase. Liposomes containing either active or heat-inactivated $\mathrm{GO}$ also served as a phagocytic particle for normal PMN, but were less efficient than latex particles in stimulating glucose $-1 .{ }^{14} \mathrm{C}$ oxidation.

\section{IODINATION ACTIVITY BY PMN LEUKOCYTES}

Phagocytosis of opsonized zymosan particles did not increase the iodination activity by CGD leukocytes (Table 4). However, iodination activity was significantly increased $(P<0.025)$ by leukocytes during phagocytosis of IgG-Lip-GO obtained from three patients with CGD. There was increasing iodinating activity with further addition of liposomes. Liposomes containing heatinactivated GO did not increase the iodination activity by CGD leukocytes. The simultaneous addition of liposomes containing either active GO or heat-inactivated GO and opsonized zymosan decreased the iodination activity of normal PMN compared to the activity obtained with zymosan alone.

\section{BACTERICIDAL ACTIVITY OF NORMAL AND CGD LEUKOCYTES}

The capacity of CGD leukocytes to kill $S$. aureus 502A was markedly impaired when compared to the killing response obtained with normal PMN (Fig. 2). In the presence of IgG-Lip-GO,

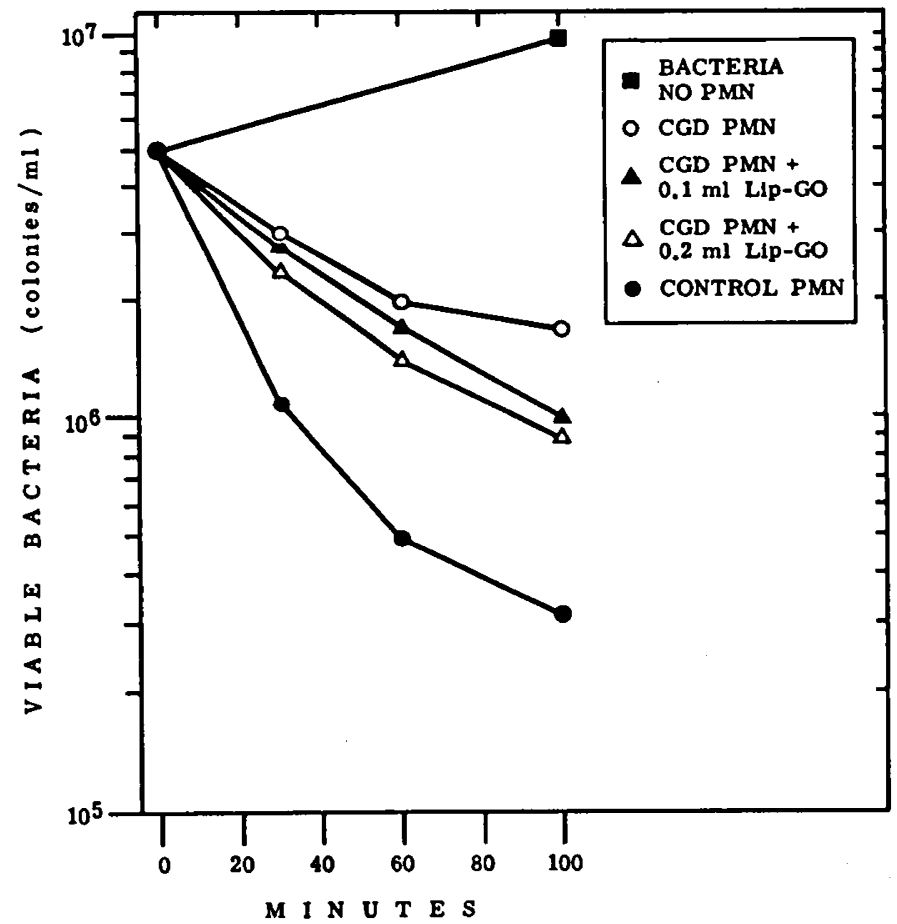

Fig. 2. The effect of IgG-Lip-Go on the bactericidal activity of CGD leukocytes. $2.5 \times 10^{6}$ PMN were incubated with an equivalent number of $S$. aureus with or without IgG-Lip-Go. The figure illustrates results obtained from a representative experiment and each point was obtained as mean colony counts from duplicate plates.

Table 2. Release of $\mathrm{H}_{2} \mathrm{O}_{2}$ from $\mathrm{CGD}$ leukocytes incubated with IgG-Lip-GO

Experimental conditions

Hydrogen peroxide release \pm SEM

PMN alone

(nmoles $\mathrm{H}_{2} \mathrm{O}_{2} / \mathrm{min} / 5 \times 10^{6} \mathrm{PMN}$ )

PMN + latex

PMN + IgG-Lip-GO

$0.042 \pm 0.013$

PMN + IgG-Lip-GO plus

$0.077 \pm 0.035$

$1.062 \pm 0.122$

Cytochalasin B $(5 \mu \mathrm{g} / \mathrm{ml})$

${ }^{1}$ CGD leukocytes $\left(5 \times 10^{6}\right.$ cells) were incubated with an equal volume of IgG-Lip-GO in the presence of $10 \%$ normal serum for $30 \mathrm{~min}$ in $37^{\circ} \mathrm{C}$ shaking water bath. The pellet and the liposomes were centrifuged at $30,000 \mathrm{rpm}$ for $25 \mathrm{~min}$. The supernatants were analyzed for $\mathrm{H}_{2} \mathrm{O}_{2}$ as described in Methods. The values shown are means for triplicate samples from two separate experiments.

Table 1. Distribution of GO activity detected after incubation of CGD leukocytes with IgG-Lip-GO

\begin{tabular}{lccc}
\hline & \multicolumn{3}{c}{ GO activity \pm SEM } \\
\cline { 2 - 4 } \multicolumn{1}{c}{ Experimental Conditions } & Pellet & Supernatant & Total \\
\hline PMN + IgG-Lip-GO & $0.62 \pm 0.07$ & $1.43 \pm 0.12$ & $2.05 \pm 0.13$ \\
PMN + IgG-Lip-GO + Cyto B $(5 \mu \mathrm{g} / \mathrm{ml})$ & $0.34 \pm 0.06$ & $1.75 \pm 0.18$ & $2.09 \pm 0.09$ \\
PMN + IgG-Lip-GO (in ice) & $0.27 \pm 0.08$ & $1.70 \pm 0.15$ & $1.97 \pm 0.11$ \\
\hline
\end{tabular}

\footnotetext{
1 Normal PMN $\left(5 \times 10^{6}\right.$ cells) were incubated with an equal volume of IgG-Lip-GO in the presence of $10 \%$ normal serum for $60 \mathrm{~min}$ in $37^{\circ} \mathrm{C}$ shaking water bath. The pellets were washed 3 times at $250 \mathrm{~g}$ for $10 \mathrm{~min}$, treated with Triton X-100 and sonication. GO activity was measured in the supernatants and pellet. The values shown are means for duplicate samples from two separate experiments and are expressed as glucose utilized per min.
} 
Table 3. The effect of IgG-Lip-GO on glucose-1-14 C oxidation by CGD leukocytes ${ }^{1}$

\begin{tabular}{lcccc}
\hline \multicolumn{1}{c}{ Experimental conditions } & Normal $^{2}$ & CGD (BF) & CGD (SB) & CGD (MF) $^{4}$ \\
\hline PMN alone & $1053 \pm 73$ & $723 \pm 62$ & 825 & 602 \\
PMN + latex & $5107 \pm 429$ & $906 \pm 50$ & 980 & 684 \\
PMN plus: & & & 1217 &. \\
0.1 ml IgG-Lip-GO & & $1520 \pm 106$ & 3240 & 1870 \\
0.2 ml IgG-Lip-GO & $3609 \pm 138$ & $2766 \pm 97$ & 360 & 2697 \\
0.3 ml IgG-Lip-GO & $2994 \pm 188$ & $3089 \pm 109$ & $1008 \pm 67$ & \\
0.3 ml IgG-Lip- $\Delta$ GO $^{5}$ & & & \\
\hline
\end{tabular}

\footnotetext{
' Experiments were done as described in Methods and values were expressed as counts per $\mathrm{min} / 30 \mathrm{~min} / 1.0 \times 10^{7}$ cells $\pm \mathrm{SEM}$.

${ }^{2}$ Mean of 4 experiments, each done in duplicate:

${ }^{3}$ Mean of 2 experiments, each done in duplicate.

${ }^{4}$ Mean of 1 experiment, each done in duplicate.

${ }^{5} \Delta \mathrm{GO}=$ heat-inactivated GO.
}

Table 4. The effect of IgG-Lip-GO on iodination activity of CGD leukocytes ${ }^{1}$

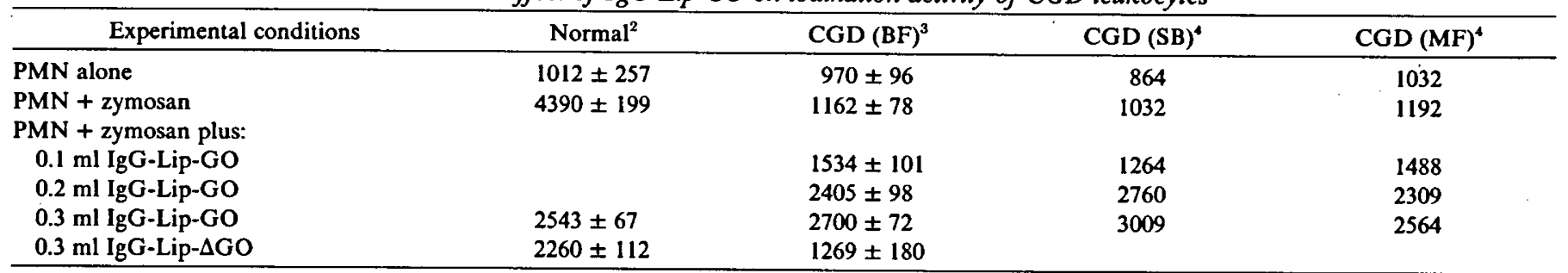

\footnotetext{
' Experiments were done as described in Methods and values were expressed as counts per $\mathrm{min} / 30 \mathrm{~min} / 1.0 \times 10^{7}$ cells $\pm \mathrm{SEM}$.

${ }^{2}$ Mean of 4 experiments, each done in duplicate.

${ }^{3}$ Mean of 2 experiments, each done in duplicate.

4 Mean of 1 experiment, each done in duplicate.

${ }^{5} \Delta \mathrm{GO}=$ heat-inactivated $\mathrm{GO}$.
}

improvement in the killing capacity of CGD leukocytes was consistently obtained. Although the extent of killing by CGD PMN in the presence of IgG-Lip-GO never reached the bactericidal efficiency of normal leukocytes, the partial correction was observed both early and at later phases of the 100 -min incubation period.

\section{DISCUSSION}

The current therapeutic approach for treatment of infections in patients with CGD involves the administration of antibiotics specifically designed to erradicate the causative microorganisms. Because the infecting catalase positive bacteria destroy their endogenous hydrogen peroxide and the CGD leukocyte is unable to generate hydrogen peroxide during phagocytosis, therapies have been designed to deliver hydrogen peroxide to the deficient CGD cells. Previous attempts to correct the intracellular defect in CGD using drugs have employed methylene blue (23), sulfisoxazole (19), trimethoprim sulfamethoxazole (22), and a dapsone derivative, 4-hydroxylaminodiphenyl sulfone (16), but this appraoch has only been partially successful.

Enzyme replacement is another potential method for correction of the oxidative deficiency in these cells. Previously, glucose oxidase bound to latex particles was introduced into CGD leukocytes in vitro as a means of providing hydrogen peroxide (5). Although improvement of the metabolic and bactericidal defect of the CGD leukocyte was obtained, the source of the hydrogen peroxide was both extracellular and intracellular. Coated latex particles could not be utilized in vivo because of the risk of inciting hypoglycemia, immune complex formation, and pulmonary embarrassment. These problems could be potentially circumvented by utilization of IgG-coated liposomes which could shield the glucose oxidase, until its selective uptake by host phagocytic cells. To test whether IgG-Lip-GO could be employed in vivo, it was necessary to evaluate their function in vitro. Of the total glucose oxidase added to liposomal preparations $5-11 \%$ could be entrapped and was only available for utilization after digestion by detergent or by phagocytic cells. Liposomes were treated with aggregated IgG which becomes associated with the liposomal surface by both electrostatic and hydrophobic interactions. The Fc portion of the IgG molecule was exposed (27), and rendered the liposomes phagocytic. The studies were conducted in the absence of fresh serum since complement has been shown to lysis liposomes (25).

The CGD leukocytes ingested the IgG-Lip-GO after phagocytosis and metabolic oxidative deficiencies of glucose- $1-{ }^{14} \mathrm{C}$ oxidation and iodination were normalized. Both of these activities have been shown to depend upon the availability of $\mathrm{H}_{2} \mathrm{O}_{2}$ within the $\operatorname{PMN}(3,18)$. On the other hand, the administration of enzyme laden liposomes to normal leukocytes failed to enhance their already stimulated phagocytes of oxidative metabolism. As others have observed, we found that cytochalasin B incompletely affected the uptake of particles (29). A modest, but reproducible improvement in the capacity to kill $S$. aureus by CGD leukocytes was observed under similar conditions. The mechanism for the improved killing capacity can be attributed to the presence of a potent $\mathrm{H}_{2} \mathrm{O}_{2}$ generating system within the phagocytic vacuole which has been previously shown to prove the substrates to complete the peroxidative iodination and killing response for viable pathogenic bacteria (20). Our inability to completely correct killing by CGD leukocytes may be related to several intracellular and extracellular effects, including steric hinderance to normal bacterial ingestion by the simultaneous presence of liposomes in the extracellular medium, the failure to provide each phagosome with either sufficient amounts of myeloperoxidase or its substrate, $\mathrm{H}_{2} \mathrm{O}_{2}$ (16), or the rapid disposal of hydrogen peroxide by the cytoplasmic enzyme, catalase. Thus, it has been possible to restore the oxidative metabolic capacities to CGD leukocytes by the introduction of GO containing liposomes to these cells and to attain moderate improvement in their bactericidal function in vitro. Further studies are required to design better methods to achieve complete restoration of bactericidal potency before in vivo studies with liposome therapy could be attempted.

\section{CONCLUSION}

Liposomes containing glucose oxidase and rendered phagocytic by coating with IgG were prepared. The enzyme within the 
liposome was demonstrated to be latent and could be activated upon treatment with detergent or after ingestion by PMN. The metabolic deficiency of CGD leukocytes could be markedly improved by the ingestion in vitro of these glucose oxidase containing liposomes. Glucose-1 $-{ }^{14} \mathrm{C}$ oxidation activity and iodination were normalized, and the bactericidal activity was partially restored. These studies show that deficient oxidase activity can be restored into CGD leukocytes by selective ingestion of liposomes containing glucose oxidase.

\section{REFERENCES AND NOTES}

1. Baehner, R. L., Gilman, N., and Karnovsky, M. L.: Respiration and glucose oxidation in human and guinea pig leukocytes: comparative studies. J. Clin. Invest., 49: 692 (1970).

2. Baehner, R. L., and Karnovsky, M. L.: Deficiency of reduced nicotinamideadenine dinucleotide oxidase in chronic granulomatous disease. Science, 162: 1277 (1968).

3. Baehner, R. L., Murrmann, S. K., Davis, J., and Johnston, R. B., Jr.: The role of superoxide anion and hydrogen peroxide in phagocytosis-associated oxidative metabolic reactions. J. Clin. Invest., 56: 571 (1975).

4. Baehner, R. L., and Nathan, D. G.: Leukocyte oxidase: defective activity in chronic granulomatous disease. Sceince, 155: 835 (1967).

5. Baehner, R. L., and Nathan, D. G.: Quantitative nitroblue tetrazolium test in chronic granulomatous disease. N. Engl. J. Med., 278: 971 (1968).

6. Baehner, R. L., Nathan, D. G., and Karnovsky, M. L.: Correction of metabolic deficiencies in the leukocytes of patients with chronic granulomatous disease. J. Clin. Invest., 49: 865 (1970).

7. Briggs, R. T., Karnovsky, M. L., and Karnovsky, M. J.: Hydrogen peroxide production in chronic granulomatous disease. A cytochemical study of reduced pyridine nucleotide oxidases. J. Clin. Invest., 59: 1088 (1977).

8. Bright, H. J., and Appleby, M.: The pH dependence of the individual steps in the glucose oxidase reaction. J. Biol. Chem., 244: 3625 (1969).

9. Curnutte, J. T., Whitten, I. M., and Babior, B. M.: Defective superoxide production by granulocytes from patients with chronic granulomatous disease. $\mathrm{N}$. Engl. J. Med., 290: 593 (1974).

10. Gregoriadis, G.: The carrier potential of liposomes in biology and medicine. $\mathbf{N}$. Engl. J. Med., 295: 704 (1976).

11. Hakim, J., Cramer, E., Boivin, P., Troube, H., and Boucherat, J.: Quantitative iodination of human blood polymorphonuclear leukocytes. Eur. J. Clin. Invest., 5: 215 (1975).

12. Hohn, D. C., and Lehrer, R. I.: NADPH oxidase deficiency in X-linked chronic granulomatous disease. J. Clin. Invest., 55: 707 (1975).

13. Holmes, B., and Page, A. R.: Studies on the metabolic activity of leukocytes from patients with a genetic abnormality of phagocytic function. J. Cell Biol., 31: 48a (1966).

14. Holmes, B., Page, A. R., and Good, R. A.: Studies of the metabolic activity of leukocytes from patients with a genetic abnormality of phagocytic function. $J$. Clin. Invest., 46: 1422 (1967).

15. Homan-Müller, J. W. T., Weening, R. S., anf Roos, D.: Production of hydrogen

Copyright (C) 1979 International Pediatric Research Foundation, Inc. $0031-3998 / 79 / 1306-0769 \$ 02.00 / 0$ peroxide by phagocytizing human granulocytes. J. Lab. Clin. Med., 85: 198 (1975).

16. Ismail, G., Boxer, L. A., Allen, J. M., and Baehner, R. L.: Improvement of polymorphonuclear leukocyte oxidative and bactericidal functions in chronic granulomatous disease with 4-amino-4'-hydroxyl-aminodiphenyl sulfone. Brit. J. Haemat. 40: 219 (1978).

17. Johnston, R. B. Jr., and Baehner, R. L.: Improvement of leukocyte bactericidal activity in chronic granulomatous disease. Blood, 35: 350 (1970).

18. Johnston, R. B., Jr., Keele, B. B. Jr., Misra, H. P., Lehmeyer, J. E., Webb, L. S., Baehner, R. L., and Rajagopalan, K. V.: The role of superoxide anion generation in phagocytic bactericidal activity. Studies with normal and chronic granulomatous disease leukocytes. J. Clin. Invest., 55: 1357 (1975).

19. Johnston, R. B. Jr., Wilfert, C. M., Buckley, R. H., Webb, L. S., DeChatelet, L. R., and McCall, C. E.: Enhanced bactericidal activity of phagocytes from patients with chronic granulomatous disease in the presence of sulphisoxazole. Lancet, 2: 824 (1975).

20. Klebanoff, S. J.: Antimicrobial mechanisms in neutrophilic polymorphonuclear leukocytes. Semin. Hematol., 12: 117 (1975).

21. Klebanoff, S. J., and White, L. R.: Iodination defect in the leukocytes of a patient with chronic granulomatous disease of childhood. N. Engl. J. Med., 280: 460 (1969).

22. Kobayashi, Y., and Usui, T.: Treatment of chronic granulomatous disease with sulfamethoxazole-trimethoprim (SMX-TMP). International Symposium on Phagocytosis, The Jikei University School of Medicine, Tokyo, Japan, p 43 (1977).

23. Philipart, A. J. Colodnj, A. H., and Bachner, R. L.: Chronic granulomatous disease of childhood. J. Ped. Surg., 4: 85 (1969).

24. Quie, P. G., White, J. G., Holmes, B., and Good, R. A.: In vitro bactericidal capacity of human polymorphonuclear leukocytes; diminished activity in chronic granulomatous disease of childhood. J. Clin. Invest., 46: 668 (1967).

25. Richards, R. L., Gervury, H., Osmond, A. P., and Aluing, C. R.: Interactions of C-reactive protein and complement with liposomes. Proc. Natl. Acad. Sci., 74: 5672 (1977).

26. Root, R, U., Metcalf, J., Oshino, N., and Chance, B.: $\mathrm{H}_{2} \mathrm{O}_{2}$ release from human granulocytes during phagocytosis. I. Documentation, quantitation, and some regulating factors. J. Clin. Invest., 55: 945 (1975).

27. Weissmann, G., Brand, A., and Franklin, E. C.: Interaction of immunoglobulins with liposomes. J. Clin. Invest., 53: 536 (1974).

28. Weissmann, G., Bloomgarden, D., Kaplan, R., Cohen, C., Hoffstein, S., Collins, T., Gotlieb, A., and Nagle, D.: A general method for the introduction of enzymes, by means of immunoglobulin-coated liposomes, into lysosomes of deficient cells. Proc. Natl. Acad. Sci., 72; 88 (1975).

29. Zigmond, S. H., and Hirsch, J. G.: Effects of cytochalasin B on polymorphonuclear leukocyte locomotion, phagocytosis and glycolysis. Exp. Cell. Res., 73: 383 (1972).

30. This research was supported in part, by grant \# PHS R01 AI 10892-06 and R01 AI 13586-03 from the NIH and by a grant from the James Whitcomb Riley Memorial Association. This work was during the tenure of an Established Investigatorship from the American Heart Association by Dr. Boxer.

31. Requests for reprints should be addressed to: Laurence A. Boxer, M.D., Department of Pediatrics, James Whitcomb Riley Hospital for Children, 1100 West Michigan Street, Indianapolis, Indiana 46202, USA.

32. Received for publication April 18, 1978.

33. Accepted for publication July 13, 1978. 